\title{
CCR2 wt Allele
}

National Cancer Institute

\section{Source}

National Cancer Institute. CCR2 wt Allele. NCI Thesaurus. Code C101578.

Human CCR2 wild-type allele is located in the vicinity of 3p21.31 and is approximately $7 \mathrm{~kb}$ in length. This allele, which encodes C-C chemokine receptor type 2 protein, is involved in both chemokine binding and signaling. 